\title{
PENGEMBANGAN BERAS ANALOG DENGAN MEMANFAATKAN JAGUNG PUTIH
}

\author{
[Development of White Corn-Based Rice Analogues]
}

\author{
Santi Noviasari ${ }^{1,2)^{\star}}$, Feri Kusnandar ${ }^{1)}$ dan Slamet Budijanto1) \\ 1) Departemen IImu dan Teknologi Pangan, Fakultas Teknologi Pertanian, Institut Pertanian Bogor, Bogor \\ 2) Jurusan Teknologi Hasil Pertanian, Fakultas Pertanian, Universitas Syiah Kuala, Banda Aceh
}

Diterima 16 Juli 2013 / Disetujui 18 Desember 2013

\begin{abstract}
White corn can be utilized as a source of non-rice carbohydrate in the manufacture of rice analogues. The rice analogues with rice-like characteristics were produced by an extrusion technique. The aim of this research was to develop rice analogues from white corn and to evaluate their physicochemical and sensory properties. The study was conducted in several stages, i.e. preparation, formulation, and physicochemical and sensory properties evaluation. The physicochemical properties of rice analogues evaluated included proximate nutritional composition, dietary fiber concentration, cooking time, water loss rate, color, and whiteness percentage, while their sensory preferences were evaluated using hedonic scale test. The rice analogues made of Pulut Harapan and Lokal Purbalingga corns (4.34:65.66\%) added with 30\% sago starch, was found to be the most preferred. The moisture, ash, protein, fat, carbohydrate, and dietary fiber composition of this rice analog was 9.32, 0.38, 6.86, 1.22, 91.54, and $5.35 \%$, respectively.
\end{abstract}

Keywords: extrusion, rice analogues, white corn

\section{ABSTRAK}

Jagung putih dapat dimanfaatkan sebagai sumber karbohidrat non beras dalam pembuatan beras analog. Beras analog dengan karakteristik menyerupai beras dihasilkan dengan penggunaan teknik ekstrusi. dapat menghasilkan beras analog yang menyerupai beras. Tujuan dari penelitian ini adalah untuk mengembangkan beras analog berbasis jagung putih serta mengevaluasi sifat fisikokimia dan sensorinya. Penelitian dilakukan dalam beberapa tahap yaitu tahap persiapan, formulasi, dan pengujian sifat fisikokimia dan sensori beras analog. Beras analog yang dihasilkan diuji sifat fisikokimia berupa kadar proksimat, kadar karbohidrat, kadar serat pangan, waktu pemasakan, laju kehilangan air, warna, derajat putih dan uji sensori dengan uji skala hedonik. Formula terbaik beras analog berdasarkan uji sensori adalah perbandingan jagung Pulut Harapan dan jagung Lokal Purbalingga 4.34:65.66\% dan pati sagu 30\%. Kadar air, abu, protein, lemak, karbohidrat dan serat pangan dari beras analog terbaik adalah berturut-turut $9.32,0.38,6.86,1.22,91.54$ dan $5.35 \%$.

Kata kunci: beras analog, ekstrusi, jagung putih

\section{PENDAHULUAN}

Beras merupakan sumber karbohidrat utama dalam pola makan masyarakat Indonesia. Tingkat ketergantungan masyarakat yang hanya terfokus pada satu sumber karbohidrat saja secara bertahap perlu dikurangi, karena akan berdampak pada ketahanan pangan.

Salah satu pendekatan dapat dilakukan melalui diversifikasi pangan yaitu pembuatan beras analog dari berbagai tepungtepungan yang berasal dari bahan baku non beras. Beras analog merupakan beras tiruan yang berbentuk seperti beras, dapat dibuat dari tepung beras non beras dengan penambahan air (Budijanto dan Yuliyanti, 2012). Beras analog dikonsumsi seperti layaknya makan nasi dari beras padi. Beras analog dapat dirancang sehingga memiliki kandungan gizi hampir sama bahkan melebihi beras padi, dan juga dapat memiliki sifat fungsional sesuai dengan bahan baku yang digunakan. Produk diversifikasi ini diharapkan dapat mendukung program

*Penulis Korespondensi:

Email: santi.zaza@yahoo.com; Telp. 08126929102 ketahanan pangan nasional dengan mengurangi tingkat konsumsi beras tanpa membuat perubahan besar dalam tradisi makan masyarakat.

Bahan baku non beras yang potensial sebagai sumber bahan pangan pokok dan dapat dimanfaatkan dalam pembuatan beras analog adalah Jagung. Di Indonesia, jagung merupakan komoditas serealia kedua sebagai penghasil karbohidrat $(75 \%)$ setelah beras dan juga mengandung kadar protein yang tinggi $(7-12 \%)$ sehingga dapat menjadi sumber protein yang baik (Ullah et al. 2010). Penelitian ini mengembangkan beras analog dengan menggunakan jagung puth, yang bertujuan selain sebagai sumber karbohidrat juga diharapkan akan menghasilkan beras analog yang berwarna putih. Penerimaan beras/nasi juga tergantung pada tingkat kepulenan nasi yang dipengaruhi oleh kandungan amilosanya. Oleh karena itu dalam penelitian ini akan digunakan jagung puth varietas Pulut Harapan yang mengandung amilosa rendah dan jagung putih varietas Lokal yang mengandung amilosa sedang. Sehingga diharapkan beras analog yang dihasilkan akan bersifat tidak terlalu pera dan tidak terlalu pulen yang dapat meningkatkan penerimaan masyarakat. 
Beras analog dapat diproduksi dengan menggunakan teknologi ekstrusi yang telah banyak digunakan dalam memproduksi berbagai produk pangan. Penerapan teknologi ekstrusi memudahkan dalam pembuatan beras analog (Mishra et al. 2012), karena paling efektif dari segi proses dan dapat menghasilkan beras analog yang menyerupai butir beras. Prinsip ekstrusi adalah proses pengolahan bahan pangan yang mengkombinasikan beberapa proses yang berkesinambungan antara lain pencampuran, pemanasan dengan suhu tinggi, pengadonan, shearing, dan pembentukan melalui cetakan (die) yang dirancang untuk membentuk hasil ekstrusi (Riaz, 2000). Beras analog dikeringkan sampai kadar air 4-15\% untuk mencapai kadar air optimal sehingga dapat meningkatkan umur simpan (Mishra et al. 2012). Penelitian ini bertujuan mendapatkan formulasi beras analog dan mengevaluasi sifat fisikokimia dan sensori dari beras analog yang dihasilkan.

\section{BAHAN DAN METODE}

\section{Bahan}

Bahan baku yang digunakan adalah jagung putih varietas Pulut Harapan (waxy) berasal dari Balai Penelitian Tanaman Sereal Maros, dipanen pada April 2012 dan varietas Lokal Purbalingga (non waxy) yang diperoleh dari Purbalingga yang dipanen pada Mei 2012, serta pati sagu dari Riau yang dipanen pada 2012. Bahan kimia yang digunakan untuk analisis antara lain enzim thermamyl, enzim pepsin, enzim pankreatin (Sigma Co., USA), gliseril mono stearat (PT. Lautan Luas, Jakarta, Indonesia), serta bahan kimia lainnya.

\section{Tahap persiapan}

Tahap ini diawali dengan pembuatan tepung jagung putih Pembuatan tepung jagung putih menggunakan metode kering (Suarni, 2009). Jagung pipilan disortasi, kemudian dilakukan penyosohan dengan menggunakan alat sosoh beras (Satake, Jepang), selanjutnya ditepungkan dengan disc mill (Satake, Jepang) dan pengayakan dengan ukuran 80 mesh.

\section{Formulasi beras analog}

Formulasi beras analog dihitung berdasarkan kadar amilosa dari jagung putih Pulut dan lokal serta pati sagu. Kadar amilosa dihitung menggunakan spectrometer UV-Vis pada panjang gelombang $589 \mathrm{~nm}$ (Williams et al. 1970). Dari hasil perhitungan diperoleh kadar amilosa dari tepung jagung Pulut $6.25 \%$, tepung jagung lokal $15.7 \%$ serta pati sagu $21.4 \%$. Formulasi beras analog selengkapnya dapat dilihat pada Tabel 1. Pada setiap formulasi ditambahkan komponen tetap yaitu air sebanyak 50\% dan Gliseril Mono Stearat (GMS) 2\% dari total adonan tepung (Budijanto dan Yuliyanti, 2012). Beras analog diproduksi dengan menggunakan Twin screw extruder (Berto BEX-DS-2256, Indonesia), melalui beberapa tahapan yaitu (1) pencampuran bahan sesuai formulasi selama 10 menit dengan dry mixer, (2) penambahan air pada adonan, (3) tahap ekstrusi (T1 = 80, T2 = $85, \mathrm{~T} 3=85$, kecepatan ulir $40 \mathrm{~Hz}$, dan kecepatan pisau $20 \mathrm{~Hz}$ ), (4) pencetakan menggunakan die dan pemotongan agar menyerupai bentuk beras, (5) tahap pengeringan hingga kadar air di bawah $15 \%$.
Tabel 1. Formulasi beras analog

\begin{tabular}{cccc}
\hline Formulasi & $\begin{array}{c}\text { Tepung Jagung } \\
\text { Pulut (\%) }\end{array}$ & $\begin{array}{c}\text { Tepung Jagung } \\
\text { Lokal (\%) }\end{array}$ & $\begin{array}{c}\text { Pati Sagu } \\
(\%)\end{array}$ \\
\hline A & 1.3 & 73.7 & 25 \\
B & 4.3 & 65.7 & 30 \\
C & 7.4 & 57.6 & 35 \\
\hline
\end{tabular}

\section{Metode analisis}

Analisis dilakukan pada bahan baku dan beras analog yang dihasilkan. Analisis pada bahan baku meliputi analisis proksimat (AOAC, 2006), kadar karbohidrat (by difference), kadar amilosa dengan metode spektrofotometer menggunakan spectrometer UV-Vis (Shimadzu, Jepang) (Williams et al. 1970), dan profil gelatinisasi dengan Rapid Visco Analyzer (RVA).

Beras analog yang dihasilkan akan dianalisis sifat fisikokimia dan sensori. Berdasarkan hasil sensori dilakukan penentuan formula terbaik sebagai hasil penelitian ini. Analisis kimia beras analog yang dihasilkan pada tahap 2 meliputi analisis proksimat (AOAC, 2006), kadar karbohidrat (by difference), kadar serat pangan metode enzimatis dengan menggunakan beberapa enzim yaitu enzim thermamyl, enzim pepsin, enzim pankreatin (Asp, 1983). Sedangkan analisis fisik meliputi waktu pemasakan, laju kehilangan air, warna menggunakan Chromameter CR 300 (Minolta, Jepang), derajat putih, dan uji sensori (Meilgaard et al. 1999).

\section{Waktu pemasakan}

Beras analog dimasak dengan rice cooker dengan perbandingan air dan beras 1:1. Air dimasak terlebih dahulu dalam rice cooker hingga mendidih. Kemudian dimasukkan beras analog dan dimasak hingga matang. Waktu pemasakan dihitung sejak beras analog dimasukkan ke dalam rice cooker hingga masak.

\section{Laju kehilangan air}

Beras analog yang telah dimasak menjadi nasi dikeluarkan dari rice cooker dan ditimbang sebagai bobot 0 menit, lalu dibiarkan pada suhu ruang dan ditimbang bobotnya setiap 30 menit selama 300 menit (5 jam). Laju kehilangan air diukur menurut rumus berikut:

$$
\text { Laju kehilangan air }\left(\mathrm{gH}_{2} \mathrm{O} / \mathrm{g} \cdot \text { menit) }\right)=\frac{\text { Bobot air yang hilang }(\mathrm{g})}{\text { bobot kering nasi }(\mathrm{g}) \times \Delta \mathrm{t}(\text { menit) }}
$$

Keterangan :

Bobot air yang hilang $(\mathrm{g})=\Delta$ bobot

= bobot awal nasi - bobot akhir nasi

Bobot kering $(\mathrm{g}) \quad=$ bobot awal - (kadar air nasi $x$ bobot awal nasi)

$\Delta \mathrm{t}$ (menit) $\quad=$ waktu akhir - waktu awal (menit)

\section{Uji sensori}

Uji sensori yang digunakan adalah uji skala hedonik dan dilakukan pada beras analog dan nasi dari beras analog berdasarkan Meilgaard et al. (1999). Uji sensori dilakukan dengan menggunakan 70 orang panelis tidak terlatih. Parameter yang diuji untuk beras analog adalah warna, aroma, bentuk dan keseluruhan, sedangkan untuk nasi dari beras analog adalah warna, aroma, rasa, tekstur dan keseluruhan. Skala hedonik yang digunakan adalah skala numerik antara 1-7 (1 = sangat 
tidak suka $-7=$ sangat suka). Teknik penyajian untuk beras analog dilakukan secara sekaligus untuk ketiga sampel, sedangkan untuk nasi analog disajikan secara satu per satu.

\section{HASIL DAN PEMBAHASAN}

\section{Karakteristik kimia bahan baku}

Pengukuran kadar amilosa dijadikan sebagai acuan dalam menyusun formulasi beras analog. Karakteristik kimia bahan baku dapat dilihat pada Tabel 2. Tepung jagung Pulut mengandung amilosa $10.80 \%$, sedangkan tepung jagung Loka mengandung amilosa $17.73 \%$. Dari penelitian Aini dan Purwiyatno (2007) kadar amilosa jagung varietas Pulut Gorontalo adalah $11.98 \%$ dan jagung varietas Lokal Canggal adalah $17.6 \%$. Hasil yang diperoleh agak berbeda karena kadar amilosa dari granula pati tergantung pada jenis varietasnya, iklim pertumbuhan, kondisi tanah selama pertumbuhan dan lain sebagainya (Sandhu et al. 2005). Kadar amilosa pati sagu yang diperoleh adalah $25.75 \%$, hasil ini lebih besar dibandingkan dengan kadar amilosa jagung. Menurut Jading et al. (2011) kadar amilosa dari pati sagu adalah $28.84 \%$.

Tabel 2. Karakteristik kimia bahan baku

\begin{tabular}{lccc}
\hline \multicolumn{1}{c}{ Karakteristik } & $\begin{array}{c}\text { Tepung Jagung } \\
\text { Pulut }\end{array}$ & $\begin{array}{c}\text { Tepung Jagung } \\
\text { Lokal }\end{array}$ & $\begin{array}{c}\text { Pati } \\
\text { Sagu }\end{array}$ \\
\hline Air $(\% \mathrm{bb})$ & $9.37 \pm 0.05$ & $12.12 \pm 0.18$ & $12.58 \pm 0.14$ \\
Abu (\% bk) & $0.67 \pm 0.01$ & $0.12 \pm 0.04$ & $0.18 \pm 0.01$ \\
Protein $(\%$ bk) & $11.48 \pm 0.09$ & $10.44 \pm 0.05$ & $0.53 \pm 0.01$ \\
Lemak $(\%$ bk) & $2.16 \pm 0.001$ & $0.40 \pm 0.08$ & $0.21 \pm 0.01$ \\
Karbohidrat $(\%$ bk) & $85.68 \pm 0.08$ & $89.04 \pm 0.07$ & $99.08 \pm 0.03$ \\
Amilosa $(\%)$ & $6.25 . \pm 0.09$ & $15.68 \pm 0.13$ & $21.38 \pm 0.03$ \\
\hline
\end{tabular}

Kadar amilosa dari bahan baku dalam pembuatan beras analog menjadi penting karena berpengaruh pada sifat dari beras dan nasi yang dihasilkan seperti tingkat kepulenan nasi dan juga sifat fungsional dari nasi tersebut. Selain itu kandungan amilosa pada beras akan mempengaruhi pengolahan beras, pemanfaatan dan mutu dari beras tersebut, terutama mutu dalam penerimaan konsumen (Avaro et al. 2009). Kadar amilosa yang tinggi biasanya menghasilkan nasi yang lebih kering dan pera dan merupakan penentu proses pemasakan serta tingkat penerimaan konsumen (Qi et al. 2010).

\section{Profil gelatinisasi bahan baku}

Profil gelatinisasi terkadang tidak seragam karena kompleksitas perilaku pati saat dipanaskan, juga dapat dipengaruhi persiapan sampel, kondisi pengukuran, leaching/pelepasan amilosa (Abdorreza et al. 2012). Profil gelatinisasi bahan baku dapat dilihat pada Tabel 3.

Profil gelatinisasi menunjukkan bahwa varietas Pulut memiliki suhu gelatinisasi yang lebih rendah $\left(77.1^{\circ} \mathrm{C}\right)$ dibandingkan jagung varietas Lokal. Hasil ini agak berbeda dari penelitian Aini dan Purwiyatno (2010) yang melaporkan suhu gelatinisasi jagung varietas Pulut adalah $71^{\circ} \mathrm{C}$. Ini disebabkan karena varietas Pulut memiliki kandungan amilosa yang lebih rendah, sehingga granula pati menyerap air lebih banyak dan tergelatinisasi pada suhu yang lebih rendah.
Tabel 3. Profil gelatinisasi bahan baku

\begin{tabular}{cccc}
\hline $\begin{array}{c}\text { Profil } \\
\text { Gelatinisasi }\end{array}$ & $\begin{array}{c}\text { Tepung Jagung } \\
\text { Pulut }\end{array}$ & $\begin{array}{c}\text { Tepung Jagung } \\
\text { Lokal }\end{array}$ & $\begin{array}{c}\text { Pati } \\
\text { Sagu }\end{array}$ \\
\hline TP $\left({ }^{\circ} \mathrm{C}\right)$ & 77.1 & 82.5 & 74.28 \\
PV $(\mathrm{cP})$ & 1950.5 & 1872 & 4189.5 \\
HPV $(\mathrm{cP})$ & 1502.5 & 1824.5 & 1624 \\
BV $(\mathrm{cP})$ & 448 & 47.5 & 2565.5 \\
CPV cP) & 2245.5 & 4578.5 & 3202.5 \\
SV $(\mathrm{cP})$ & 743 & 2754 & 1578.5 \\
\hline
\end{tabular}

Keterangan/remark: TP: suhu awal gelatinisasi/temperature pasting, PV viskositas puncak/peak viscosity, HPV : viskositas pasta panas/hot paste viscosity, BV : viskositas breakdown/breakdown viscosity : PV - HPV, CPV viskositas pasta dingin/cold paste viscosity), SV : viskositas setback/setback viscosity : CPV - HPV

Secara umum pati varietas Pulut memiliki suhu gelatinisasi yang rendah, viskositas puncak dan breakdown (kestabilan pasta pati terhadap pemanasan) yang tinggi namun viskositas setback (kecenderungan retrogradasi pati) yang rendah (Schirmer et al. 2013), pernyataan ini sesuai dengan hasil penelitian yang diperoleh. Ketika pati dipanaskan dalam air secukupnya, kestabilan ikatan hidrogen struktur double heliks dalam kristalin rusak dan digantikan oleh ikatan hidrogen dengan air, amilosa akan mengalami leaching/lepas dari granula pati. Selanjutnya amilosa dan amilopektin akan mengalami hidrasi yang mengakibatkan viskositas meningkat hingga mencapai puncak dan suspensi pati menjadi lebih jernih. Selama pemanasan lanjutan menyebabkan disintegrasi cepat dari pembengkakan granula pati atau menurunnya viskositas secara tiba-tiba, akibatnya viskositas breakdown besar. Setelah pendinginan, viskositas pasta hanya naik sedikit yang mengindikasikan sedikitnya amilosa sehingga viskositas setback rendah (Aini dan Purwiyatno, 2010; Schirmer et al. 2013).

Suhu gelatinisasi pati sagu adalah $74.28^{\circ} \mathrm{C}$, hasil ini mendekati suhu gelatinisasi yang diperoleh oleh Karim et al. (2008) dan Abdorreza et al. (2012) yaitu 75.3 dan $75.7^{\circ} \mathrm{C}$. Viskositas puncak pati sagu yang diperoleh adalah $4189.5 \mathrm{cP}$. viskositas breakdown $2565.5 \mathrm{cP}$ dan viskositas setback 1578.5. Hasil pengamatan mendekati hasil yang diperoleh Karim et al. (2008) yaitu viskositas puncak pati sagu adalah $4596 \mathrm{cP}$, breakdown $2830.8 \mathrm{cP}$ dan setback $894 \mathrm{cP}$.

\section{Karakteristik kimia beras analog}

Sifat fisikokimia pada beras analog adalah kadar proksimat dan serat pangan (Tabel 4). Kadar air ketiga beras analog sudah lebih rendah dari kadar air yang aman untuk penyimpanan beras yaitu $<14 \%$ (bb). Pada kadar air $<14 \%$ (bb) akan mencegah pertumbuhan kapang yang sering mengganggu pada serealia/biji-bijian selama penyimpanan.

Kadar protein beras analog lebih rendah dibandingkan dengan beras sosoh. Kadar protein yang dihasilkan sangat tergantung pada kondisi operasi ekstruder dan bahan-bahan yang digunakan (Akdogan, 1999). Selain sebagai sumber energi ternyata beras/nasi juga menjadi sumber protein karena tingkat konsumsi beras/nasi yang tinggi dibandingkan dengan sumber protein yang lain. Kadar protein dapat mempengaruhi kadar glukosa darah. Protein dapat menurunkan respon glikemik yang disebabkan karena protein dapat memperpanjang laju pengosongan lambung sehingga laju pencernaan dan absorpsi di dalam usus halus juga lebih lambat (Alsaffar, 2011). 
$\underline{\text { Tabel 4. Kadar proksimat dan serat pangan beras analog }}$

\begin{tabular}{lcccc}
\hline Komposisi & $\begin{array}{c}\text { Formula } \\
\text { A }\end{array}$ & $\begin{array}{c}\text { Formula } \\
\text { B }\end{array}$ & $\begin{array}{c}\text { Formula } \\
\text { C }\end{array}$ & $\begin{array}{c}\text { Beras } \\
\text { Sosoh }^{*}\end{array}$ \\
\hline Air (\%) & $6.35 \pm 0.30^{\mathrm{a}}$ & $9.32 \pm 0.12^{\mathrm{b}}$ & $6.30 \pm 0.01^{\mathrm{a}}$ & $11.22 \pm 0.11$ \\
Abu (\% bk) & $0.32 \pm 0.01^{\mathrm{a}}$ & $0.38 \pm 0.11^{\mathrm{a}}$ & $0.32 \pm 0.03^{\mathrm{a}}$ & $0.56 \pm 0.0$ \\
$\begin{array}{l}\text { Lemak } \\
(\% \mathrm{bk})\end{array}$ & $1.96 \pm 0.08^{\mathrm{b}}$ & $1.22 \pm 0.03^{\mathrm{a}}$ & $1.20 \pm 0.01^{\mathrm{a}}$ & $1.46 \pm 0.1$ \\
$\begin{array}{l}\text { Protein } \\
(\% \mathrm{bk})\end{array}$ & $7.26 \pm 0.04^{\mathrm{c}}$ & $6.86 \pm 0.11^{\mathrm{b}}$ & $6.47 \pm 0.08^{\mathrm{a}}$ & $7.40 \pm 0.0$ \\
$\begin{array}{l}\text { Karbohidrat } \\
(\% \text { bk) }\end{array}$ & $90.46 \pm 0.04^{\mathrm{a}}$ & $91.54 \pm 0.03^{\mathrm{b}}$ & $92.01 \pm 0.05^{\mathrm{c}}$ & 89.56 \\
$\begin{array}{l}\text { Serat larut } \\
(\%)\end{array}$ & $1.08 \pm 0.02^{\mathrm{a}}$ & $1.49 \pm 0.08^{\mathrm{b}}$ & $1.89 \pm 0.10^{\mathrm{c}}$ & $<0.5$ \\
$\begin{array}{l}\text { Serat tidak } \\
\text { larut }(\%)\end{array}$ & $3.37 \pm 0.12^{\mathrm{a}}$ & $3.85 \pm 0.10^{\mathrm{b}}$ & $3.86 \pm 0.02^{\mathrm{b}}$ & 0.6 \\
$\begin{array}{l}\text { Serat total } \\
\text { (\%) }\end{array}$ & $4.45 \pm 0.10^{\mathrm{a}}$ & $5.35 \pm 0.18^{\mathrm{b}}$ & $5.75 \pm 0.12^{\mathrm{b}}$ & 0.6
\end{tabular}

(\%)

Keterangan: Rataan \pm standar deviasi; angka yang diikuti huruf yang sama pada baris yang sama menunjukkan perbedaan yang tidak nyata $(p>0.05)$

* Ohtsubo et al. (2005)

Kadar karbohidrat pada beras analog yang diperoleh cukup tinggi, yang disebabkan oleh penggunaan bahan baku berupa tepung dan pati yang merupakan sumber karbohidrat. Karbohidrat merupakan salah satu komponen terbesar yang menyumbangkan energi terhadap tubuh. Tingginya kadar karbohidrat yang diperoleh sehingga beras analog dapat dijadikan sebagai salah satu sumber karbohidrat selain beras.

Serat pangan pada beras analog cukup tinggi yaitu 4.45$5.75 \%$, sangat jauh dibandingkan dengan beras sosoh. Menurut Foschia et al. (2013) makanan sebagai sumber serat jika mengandung serat pangan minimal 3\%. Sedangkan makanan tinggi serat jika mengandung serat pangan minimal $6 \%$. Berdasarkan pernyataan tersebut maka beras analog yang dihasilkan sudah dapat dikatakan sebagai makanan sumber serat pangan. Sumber serat terutama diperoleh dari tepung jagung yang merupakan penyusun utama beras analog. Serat pangan memiliki karakteristik yang diperlukan dan dianggap sebagai unsur penting dalam formulasi makanan fungsional (Cuenca et al. 2008). Serat pangan larut berhubungan dengan penurunan respon glikemik (Elleuch et al. 2011). Serat pangan larut di dalam pencernaan akan membentuk tekstur semacam gel, sehingga memperlambat kecepatan pencernaan di dalam usus, memberikan rasa kenyang yang lebih lama, serta memperlambat kemunculan glukosa darah. Selain itu juga dapat menjaga kadar gula darah stabil karena kebutuhan insulin untuk mentransfer glukosa ke dalam sel-sel tubuh dan diubah menjadi energi semakin sedikit (Alsaffar, 2011). Sedangkan fungsi serat pangan tak larut adalah mencegah timbulnya berbagai penyakit, terutama yang berhubungan dengan saluran pencernaan, antara lain wasir, divertikulosis dan kanker usus besar (Eckel, 2003). Menurut Foster-Powell et al. (2002) beras yang mengandung serat pangan tinggi akan menurunkan respon glikemik dan indeks glikemiknya (IG) cenderung rendah.

\section{Karakteristik fisik beras analog}

Karakteristik fisik yang dilakukan adalah waktu pemasakan, laju kehilangan air, derajat putih dan warna. Waktu pemasakan nasi analog $A, B$ dan $C$ adalah berturut-turut $3.80,4.06$, dan 3.53 yang tidak berbeda nyata $(p>0.05)$. Hal ini diduga karena ketiga nasi analog memiliki bahan baku yang sama.
Laju kehilangan air merupakan proses untuk melihat penurunan bobot dari nasi analog akibat kehilangan air setelah dimasak. Pada penelitian ini waktu pengamatan dilakukan selama 5 jam dan parameter yang diamati adalah laju 1st falling down (laju penurunan akibat hilangnya air di 30 menit pertama), Constant Rate Period (periode laju konstan-CRP), bobot air yang hilang dan kadar air nasi analog. Hasil analisis laju $1^{\text {st }}$ falling down, bobot air yang hilang, dan kadar air nasi analog dapat dilihat pada Tabel 5 .

Tabel 5. Laju $1^{\text {st }}$ falling down, bobot air yang hilang, dan kadar air nasi analog

\begin{tabular}{cccc}
\hline $\begin{array}{c}\text { Formula } \\
\text { Nasi Analog }\end{array}$ & $\begin{array}{c}\text { Laju 1st Falling Down } \\
\left(\mathrm{gH}_{2} \mathrm{O} / \mathrm{g} \cdot \mathrm{meni}\right)\end{array}$ & $\begin{array}{c}\text { Bobot Air yang } \\
\text { Hilang }(\mathrm{g})\end{array}$ & $\begin{array}{c}\text { Kadar Air Nasi } \\
\text { Analog }(\%)\end{array}$ \\
\hline A & $0.0019 \pm 0.00^{\mathrm{a}}$ & $3.2208 \pm 0.13^{\mathrm{a}}$ & $53.05 \pm 2.01$ \\
$\mathrm{~B}$ & $0.0018 \pm 0.00^{\mathrm{a}}$ & $3.2734 \pm 0.50^{\mathrm{a}}$ & $49.23 \pm 0.16$ \\
C & $0.0015 \pm 0.00^{\mathrm{a}}$ & $3.2263 \pm 0.14^{\mathrm{a}}$ & $47.52 \pm 2.93$ \\
Nasi & $0.0026 \pm 0.00$ & $3.3605 \pm 0.16$ & $67.34 \pm 0.91$
\end{tabular}

Keterangan: Rataan \pm standar deviasi; angka yang diikuti huruf yang sama pada kolom yang sama menunjukkan perbedaan yang tidak nyata $(p>0.05)$

Laju 1 st falling down menunjukkan laju hilangnya air di 30 menit pertama. Laju ini merupakan laju penurunan bobot terbesar. Penurunan ini disebabkan adanya perbedaan suhu rice cooker dengan suhu lingkungan pada kondisi ruang. Hal ini menyebabkan nasi analog yang masih mengandung banyak air, saat didiamkan pada suhu ruang terjadi penguapan air yang besar dari permukaan nasi analog selama 30 menit pertama. Pada masa ini kadar air yang menguap adalah kadar air di permukaan nasi dan kadar air dipermukaan nasi akan lebih rendah daripada di bagian dalam nasi. Laju $1^{\text {st }}$ falling down ketiga beras analog tidak berbeda nyata $(p>0.05)$. Laju $1^{\text {st }}$ falling down pada nasi lebih besar dibandingkan nasi analog, hal ini diduga karena metode pemasakan yang berbeda. Pada pemasakan nasi jumlah air yang digunakan lebih banyak yaitu 2 bagian dari jumlah beras (2:1). Sehingga jumlah air yang diserap oleh nasi lebih banyak, hal tersebut menyebabkan laju 1 st falling down lebih besar. Laju kehilangan air setiap 30 menit nasi analog dapat dilihat pada Gambar 1 .

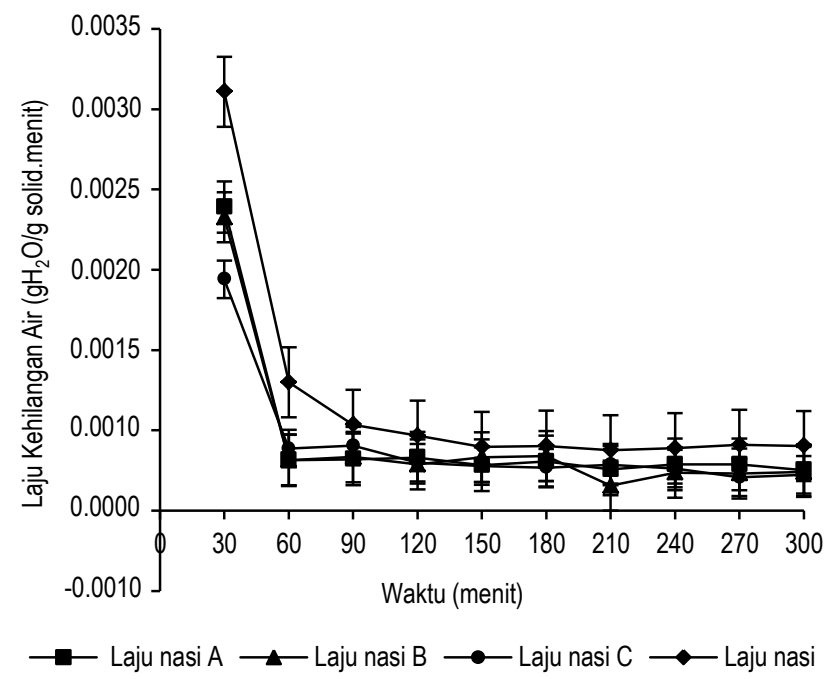

Gambar 1. Laju kehilangan air nasi analog 
Selanjutnya pada 60 hingga 300 menit kadar air yang menguap merupakan kadar air yang disuplai dari dalam nasi sehingga laju kehilangan air yang terjadi cenderung konstan. Tahap ini disebut Constant Rate Period (CRP). Nilai CRP untuk beras $\mathrm{A}, \mathrm{B}$ dan $\mathrm{C}$ adalah $0.0003 \mathrm{~g} \mathrm{H}_{2} \mathrm{O} / \mathrm{g}$.menit sedangkan untuk nasi lebih besar yaitu $0.0004 \mathrm{gH}_{2} \mathrm{O} / g$.menit. Semakin lama penyimpanan laju yang terjadi semakin menurun. Hal ini terjadi karena jumlah air pada nasi analog sudah mulai berkurang sehingga laju kehilangan air yang terjadi juga semakin kecil.

Bobot air yang hilang pada nasi analog dihitung dengan mengukur bobot nasi awal ( 0 menit) dikurangi dengan bobot nasi setelah pengukuran selama 5 jam (300 menit). Semakin banyak jumlah air yang hilang menunjukkan semakin lemah nasi menahan air. Pada Tabel 5 terlihat bahwa bobot air yang hilang ketiga nasi analog tidak berbeda nyata $(p>0.05)$. Bobot air nasi lebih besar dibandingkan dengan nasi analog. Hal ini diduga karena nasi memiliki kadar air yang lebih besar yaitu $67.34 \%$ sehingga bobot air yang hilang juga lebih besar.

Selama penyimpanan di suhu ruang terjadi perubahan tekstur pada permukaan nasi analog. Pada 30 menit pertama penyimpanan permukaan nasi masih lembut dan terlihat basah, namun semakin lama penyimpanan permukaan nasi analog terlihat kering yang disebabkan karena hilangnya atau menguapnya air dari nasi analog.

Secara umum beras analog dari ketiga formulasi memilik warna dan bentuk yang hampir sama. Beras analog yang diperoleh dapat dilihat pada Gambar 2(a), dan nasi analog yang telah dimasak dapat dilihat pada Gambar 2(b). Nasi yang dihasilkan dari segi bentuk hampir mendekati nasi yang berasal dari padi, hanya warnanya belum seputih nasi dari padi. Hal ini dapat terlihat pada analisis warna yang dilakukan, selengkapnya dapat dilihat pada Tabel 6 .

Analisis warna dilakukan dengan menggunakan Chromameter. Notasi $\mathrm{L}^{*}$ menunjukkan tingkat kecerahan suatu produk.Formula $\mathrm{C}$ memiliki tingkat kecerahan paling tinggi diikuti formula B dan A. Nilai untuk $L^{*}$ adalah berkisar dari 0 (hitam) 100 (putih). Nilai $L^{*}$ untuk ketiga formula berkisar antara 71.5271.76, nilai ini menunjukkan tingkat kecerahan ketiga beras hampir mendekati warna putih. Namun nilai $L^{*}$ beras analog masih lebih rendah dibandingkan dengan beras sosoh yaitu 80.54. Nilai ${ }^{\circ}$ Hue merupakan warna yang mengandung warna dasar Red Green Blue (RGB). Nilai ${ }^{\circ}$ Hue berdasarkan hasil uji statistik berbeda nyata untuk ketiga formulasi, nilainya berkisar antara 88.73-89.32 yang berada pada kisaran 54-90 yang menunjukkan bahwa produk mengandung warna pada kisaran merah kekuningan. Nilai ${ }^{\circ} \mathrm{Hue}$ beras sosoh masih lebih tinggi yaitu 89.06. Nilai derajat putih beras juga lebih tinggi dari beras analog yaitu $80.23 \%$. Hal ini menunjukkan bahwa warna beras analog masih berbeda dan belum putih seperti beras.

\section{Sensori beras analog}

Hasil uji sensori beras analog dapat dilihat pada Tabel 7 . Warna beras analog seperti terlihat pada Gambar 2(a) adalah puth agak krem. Aroma beras analog sangat ditentukan oleh bahan baku yang digunakan. Tepung jagung putih tidak memiliki aroma yang tajam, sehingga aroma beras analog tidak beraroma jagung.

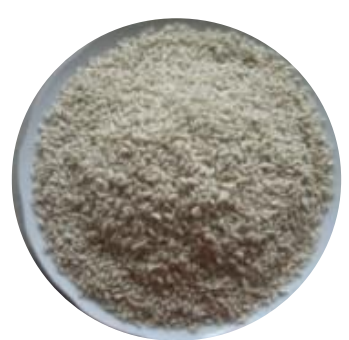

A

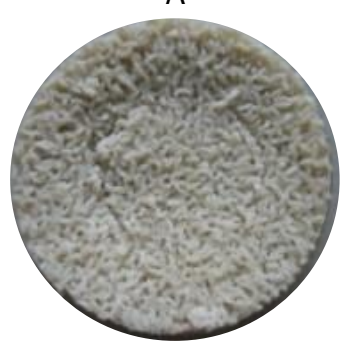

A

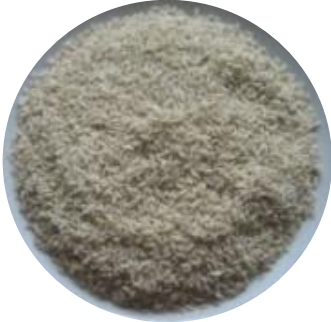

B

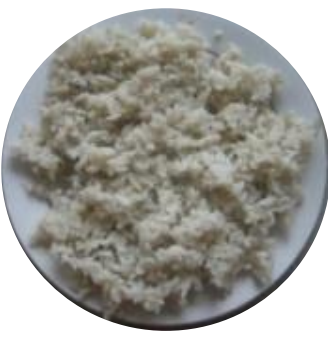

B

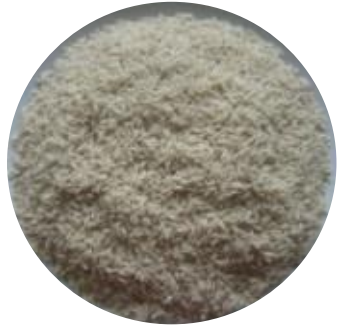

C

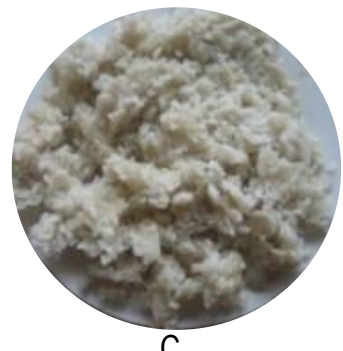

C (a)

(b)

Tabel 6. Nilai $L^{*},+a,+b,{ }^{\circ H u e ~ d a n ~ d e r a j a t ~ p u t i h ~ b e r a s ~ a n a l o g ~}$

\begin{tabular}{cccccc}
\hline Formula Beras Analog & $\mathrm{L}^{*}$ & $+\mathrm{a}$ & $+\mathrm{b}$ & ${ }^{\mathrm{o}} \mathrm{Hue}$ & Derajat Putih $(\%)$ \\
\hline A & $71.52 \pm 0.01^{\mathrm{a}}$ & $0.35 \pm 0.01^{\mathrm{c}}$ & $15.62 \pm 0.00^{\mathrm{a}}$ & $88.73 \pm 0.04^{\mathrm{a}}$ & $66.13 \pm 0.14^{\mathrm{a}}$ \\
B & $71.66 \pm 0.04^{\mathrm{b}}$ & $0.32 \pm 0.00^{\mathrm{b}}$ & $17.23 \pm 0.01^{\mathrm{b}}$ & $88.94 \pm 0.00^{\mathrm{b}}$ & $66.81 \pm 0.10^{\mathrm{b}}$ \\
C & $71.76 \pm 0.03^{\mathrm{c}}$ & $0.21 \pm 0.00^{\mathrm{a}}$ & $17.69 \pm 0.01^{\mathrm{c}}$ & $89.32 \pm 0.00^{\mathrm{c}}$ & $66.66 \pm 0.10^{\mathrm{b}}$ \\
Beras sosoh & $80.54 \pm 0.03$ & $0.25 \pm 0.03$ & $15.38 \pm 0.01$ & $89.06 \pm 0.11$ & $80.23 \pm 0.00$ \\
\hline
\end{tabular}

Keterangan: Rataan \pm standar deviasi; angka yang diikuti huruf yang sama pada kolom yang sama menunjukkan perbedaan yang tidak nyata $(p>0.05)$ 
Tabel 7. Hasil uji sensori beras analog

\begin{tabular}{ccccc}
\hline Beras Analog & Warna & Aroma & Bentuk & Keseluruhan \\
\hline A & $3.80 \pm 1.30^{\mathrm{a}}$ & $4.57 \pm 1.09^{\mathrm{a}}$ & $4.20 \pm 1.39^{\mathrm{a}}$ & $4.24 \pm 1.09^{\mathrm{a}}$ \\
B & $5.07 \pm 1.18^{\mathrm{b}}$ & $4.61 \pm 1.07^{\mathrm{ab}}$ & $5.60 \pm 0.80^{\mathrm{c}}$ & $6.20 \pm 0.94^{\mathrm{b}}$ \\
C & $4.73 \pm 1.05^{\mathrm{b}}$ & $4.79 \pm 1.02^{\mathrm{b}}$ & $4.84 \pm 1.06^{\mathrm{b}}$ & $4.83 \pm 0.93^{\mathrm{a}}$ \\
\hline
\end{tabular}

Keterangan: Rataan \pm standar deviasi; angka yang diikuti oleh huruf yang sama pada kolom yang sama menunjukkan perbedaan yang tidak nyata ( $p>0.05)$

Tabel 8. Hasil uji sensori nasi analog

\begin{tabular}{cccccc}
\hline Nasi Analog & Warna & Aroma & Rasa & Tekstur & Keseluruhan \\
\hline A & $3.96 \pm 1.32^{\mathrm{b}}$ & $3.94 \pm 1.36^{\mathrm{a}}$ & $3.56 \pm 1.34^{\mathrm{a}}$ & $3.19 \pm 1.48^{\mathrm{a}}$ & $3.54 \pm 1.22^{\mathrm{a}}$ \\
B & $4.93 \pm 0.94^{\mathrm{c}}$ & $4.13 \pm 1.32^{\mathrm{a}}$ & $4.87 \pm 1.05^{\mathrm{c}}$ & $4.63 \pm 1.29^{\mathrm{c}}$ & $4.99 \pm 0.81^{\mathrm{c}}$ \\
C & $4.27 \pm 1.15^{\mathrm{b}}$ & $3.89 \pm 1.25^{\mathrm{a}}$ & $4.33 \pm 1.27^{\mathrm{b}}$ & $4.16 \pm 1.27^{\mathrm{b}}$ & $4.20 \pm 1.11^{\mathrm{b}}$ \\
\hline
\end{tabular}

Keterangan: Rataan \pm standar deviasi; angka yang diikuti oleh huruf yang sama pada kolom yang sama menunjukkan perbedaan yang tidak nyata ( $p>0.05$ )

Secara umum bentuk yang dihasilkan dari ketiga formula tidak jauh berbeda, beras analog B memiliki bentuk yang paling mendekati dengan beras pada pada umumnya, sedangkan beras analog $\mathrm{A}$ berbentuk agak lebih besar dan beras analog $\mathrm{C}$ berbentuk agak lebih kecil dan tipis. Secara keseluruhan beras analog $B$ lebih disukai dan berbeda nyata dengan kedua beras yang lain. Hal ini menunjukkan secara keseluruhan (warna, aroma dan bentuk) beras B lebih disukai kerena menghasilkan warna puth, aroma yang netral dan memiliki bentuk yang menyerupai beras.

\section{Sensori nasi dari beras analog}

Hasil uji sensori pada nasi analog dapat dilihat pada Tabel 8. Warna yang paling disukai adalah nasi formula B karena memiliki warna yang lebih putih dibandingkan yang lain. Warna nasi seperti yang terlihat pada Gambar 2(b) adalah putih agak krem, masih berbeda dengan nasi putih yang berasal dari padi. Rasa yang dihasilkan dari nasi beras analog adalah hambar (plain) sehingga akan lebih enak jika dikonsumsi dengan menggunakan lauk pauk atau dilakukan pengolahan lanjutan seperti nasi goreng.

Tekstur merupakan salah satu parameter yang penting dalam penerimaan nasi, yang meliputi kepulenan dan kelengketan. Tekstur nasi dari formulasi B paling mendekati nasi pada umumnya, teksturnya pas (sedang) tidak pera dan tidak pulen. Tekstur nasi dari formulasi A agak pera dan nasi formulasi $\mathrm{C}$ agak pulen, secara umum panelis kurang menyukai nasi yang pulen dan pera.

Secara keseluruhan nasi formulasi $B$ paling disukai dan berbeda nyata dengan nasi formula $\mathrm{A}$ dan $\mathrm{C}$. Hal ini menunjukkan bahwa secara keseluruhan (warna, rasa dan tekstur) beras B lebih disukai kerena menghasilkan warna puth, rasa enak dan tekstur yang menyerupai nasi secara umum. Berdasarkan hasil uji sensori beras dan nasi analog maka formula $B$ merupakan formula terbaik.

\section{KESIMPULAN}

Pemanfaatan jagung putih dalam pembuatan beras analog mampu menghasilkan beras analog dengan warna dan tekstur yang baik. Formula terbaik berdasarkan uji sensori adalah formula dengan pati sagu $30 \%$, perbandingan jagung Pulut dan jagung Lokal $4.34: 65.66 \%$. Beras analog yang dihasilkan memiliki bentuk paling mendekati beras, dan nasi berwarna putih agak krem serta memiliki tekstur yang pas (tidak pera dan tidak pulen). Komposisi formula terbaik adalah kadar air $9.32 \%$, kadar abu $0.38 \%$, kadar protein $6.86 \%$, kadar lemak $1.22 \%$, kadar karbohidrat $91.54 \%$, serat pangan larut $1.49 \%$, serat pangan tidak larut $3.85 \%$ dan serat pangan total $5.35 \%$, nilai L * 71.66, 'Hue 88.94 dan derajat putih $66.81 \%$. Waktu pemasakan yang dibutuhkan adalah 4.06 menit.

\section{UCAPAN TERIMA KASIH}

Penelitian ini dibiayai oleh Program Penelitian Unggulan Strategis Nasional Dana DIPA IPB sesuai dengan Surat Perjanjian Kerja (SPK) Nomor: 29/IT3.41.2/L1/SPK/2013 tanggal: 2 Mei 2013.

\section{DAFTAR PUSTAKA}

Abdorreza MN, Robal M, Cheng LH, Tajul AY, Karim AA. 2012. Physicochemical, thermal, and rheological properties of acid-hydrolyzed sago (Metroxylon sagu) starch. LWT-J Food Sci Tech 46: 135-141. DOI: 10.1016/j.Iwt.2011.10.015.

Aini N, Purwiyatno H. 2007. Pasta pati jagung puth waxy dan non-waxy yang dimodifikasi secara oksidasi dan asetilasioksidasi. J IImu Pert Indonesia 12: 108-115.

Aini N, Purwiyatno H. 2010. Gelatinization properties of white maize starch from three varieties of corn subject to oxidized and acetylated-oxidized modification. J Int Food Res 17: 961-968.

Akdogan H. 1999. High moisture food extrusion. Int J Food Sci Tech 34: 195-207. DOI: 10.1046/j.1365-2621.1999.00256.x

Alsaffar AA. 2011. Effect of food processing on the resistant starch content of cereals and cereals products - a review. Int J Food Sci Tech 46: 455-462. DOI: 10.1111/j.13652621.2010.02529.x.

[AOAC] Association of Official Analytical Chemists. 2006. Official Methods of Analysis of The Association of Official Agriculture Chemist [sixteenth edition], Virginia.

Asp NG, Johansson CG, Hallmer H, Siljestrom. 1983. Rapid enzymatic assay of insoluble and soluble dietary fiber. J Agr Food Chem 31: 476-482. DOI: 10.1021/jf00117a003. 
Avaro MRA, Tong L, Yoshida T. 2009. A simple and low-cost method to classify amylose content of rice using a standard color chart. J Plant Prod Sci 12: 97-99. DOl: 10.1626/ pps.12.97.

Budijanto S, Yuliyanti. 2012. Studi persiapan tepung sorgum (Sorghum bicolor L. Moench) dan aplikasinya pada pembuatan beras analog. J Teknol Pertanian 13: 177-186.

Cuenca AR, Suarez MJV, Aparicio IM. 2008. Soybean seeds and its by-product okara as sources of dietary fibre. Measurement by AOAC and Englyst methods. J Food Chem 8: 1099-1105. DOI: 10.1016/j.foodchem.2007.11.061.

Eckel RH. 2003. A new look at dietary protein in diabetes. Am J Clin Nutr 78: 671-672.

Elleuch M, Bedigian D, Roiseux O, Besbes S, Blecker C, Attia H. 2011. Dietary fibre and fibre-rich by-products of food processing: Characterisation, technological functionality and commercial applications: A review. J Food Chem 124: 411. 421. DOI: 10.1016/j.foodchem.2010.06.077.

Foschia M, Peressini D, Sensidoni A, Brennan CS. 2013. The effects of dietary fibre addition on the quality of common cereal products. J Cereal Sci 58: 216-227. DOI: 10.1016/ j.jcs.2013.05.010.

Foster-Powell KF, Holt SHA, Miller JCB. 2002. International table of glicemic index and glycemic load values. Am J Clin Nutr 76: 5-56.

Jading A, Tethool E, Payung P, Gultom S. 2011. Karakteristik fisikokimia pati sagu hasil pengeringan secara fluidisasi menggunakan alat pengering Cross Flow Fluidized Bed bertenaga surya dan biomassa. J Reaktor 13: 155-164.

Karim AA, Tie APL, Manan DMA, Zaidul ISM. 2008. Starch from the sago (Metroxylon sagu) palm tree-properties, prospects, and challenges as a new industrial source for food and other uses. Compr Rev Food Sci F 7: 215-228. DOI: 10.1111/ j.1541-4337.2008.00042.x.

Meilgaard MC, Civille GV, Carr BT. 1999. Sensory Evaluation Techniques [fourth etition]. CRC Press, Boca Raton, US.
Mishra A, Mishra HN, Rao PS. 2012. Preparation of rice analogues using extrusion technology [Review]. Int J Food Sci Tech 47: 1789-1797. DOI: 10.1111/j.1365-2621.2012. 03035.x.

Ohtsubo K, Suzuki K, Yasui Y, Kasumi T. 2005. Bio-functional components in the processed pre-germinated brown rice by a twin-screw extruder. J Food Comp Anal 18: 303-316. DOI: 10.1016/j.jca.2004.10.003.

Qi WX, Qing YL, Zhi SG, Li X, Quan LQ. 2010. Determination of amylose content and its relationship with RVA profile within genetically similar cultivars of Rice (Oryza sativa L. ssp. Japonica). Agric Sci China 9: 1101-1107. DOI: 10.1016/ S1671-2927(09)60196-6.

Riaz MN. 2000. Extruders in Food Applications. CRC Press Inc, Boca Raton, US.

Sandhu KS, Singh N, Malhi NS. 2005. Physicochemical and thermal properties of starches separated from corn produced from crosses of two germ pools. J Food Chem 89: 541-548. DOI: 10.1016/j.foodchem.2004.03.007.

Schirmer M, Hochstotter A, Jekle M, Arendt E, Becker T. 2013. Physicochemical and morphological characterization of different starches with variable amylose/amylopectin ratio. J Food Hydrocolloid 32: 52-63. DOI: 10.1016/j.foodhyd. 2012.11.032.

Suarni. 2009. Prospek pemanfaatan tepung jagung untuk kue kering (cookies). J Litbang Pertanian 28: 63-71.

Ullah I, Ali M, Faroogi A. 2010. Chemical and nutritional properties of some maize (Zea mays L.) varieties grown in NWFP, Pakistan. J Nutr 9: 1113-1117. DOI: 10.3923/pjn. 2010.1113.1117.

Williams PC, Kuzina FD, Hlynka I. 1970. A rapid colorimetric procedure for estimating the amylose content of starches and flours.Board of grain commissioners. Winnioeg 2, Manitoba, Canada: Grain Res Laboratory 47: 411-420. 